\title{
PERCEPTION OF JOB-SEEKING GRADUATES IN OYO STATE NIGERIA TO CASHEW PRODUCTION
}

\section{Aremu-Dele Olufemi ${ }^{1 *}$, Adesanya Kehinde Ademola ${ }^{2}$, Nduka Abanum Beatrice ${ }^{1}$, Bakare Ayodeji Ajibola ${ }^{1}$ and Rahman Saheed Bayonle ${ }^{2}$}
${ }^{1}$ Agronomy Section, Cocoa Research Institute of Nigeria, Idi- Ayunre, Ibadan, Oyo State, Nigeria.

${ }^{2}$ Department of Economics and Extension, Cocoa ResearchInstitute of Nigeria, Idi-Ayunre, Ibadan, Oyo State, Nigeria.

Corresponding E-mail: aremudeleolufemi@gmail.com

Cite this article:

Aremu-Dele O., Adesanya K.A., Nduka A.B., Bakare A.A., Rahman S.B. (2021), Perception of Job-Seeking Graduates in Oyo State Nigeria to Cashew Production. African Journal of Agriculture and Food Science 4(4), 46-55. DOI: $10.52589 / \mathrm{AJAFS}$ AN6DOQFL.

\section{Manuscript History}

Received: 26 Oct 2021

Accepted: 29 Nov 2021

Published: 17 Dec 2021

Copyright $\odot 2020$ The Author(s). This is an Open Access article distributed under the terms of Creative Commons AttributionNonCommercial-NoDerivatives 4.0 International (CC BY-NC-ND 4.0), which permits anyone to share, use, reproduce and redistribute in any medium, provided the original author and source are credited.
ABSTRACT: Cashew is an important and commercially grown cash crop in Oyo state and Nigeria generally for its apple and most importantly the nuts. Cashew cultivation in recent years has experienced a yield decline due to few cashew farmers involved and moribund cashew trees. This paper aims to understand the perception of job-seeking graduates in Oyo state to cashew production and proffer recommendations that will help in promoting their participation. Some selected areas were considered in Oyo state and data were collected using a questionnaire on socio-demographic characteristics of the respondent, awareness on cashew tree and its importance, opinion of respondents to cashew farming, perception of respondents to money-making opportunities in cashew production and categorization of the respondents based on their level of perception. 270 respondents were considered in the survey. Data were analyzed using the SPSS statistical package. Results showed that $45.5 \%$ of the unemployed graduates were between the ages of 30-34 years. The study also showed that 90.7\% know the economic importance of cashew while $89.3 \%$ know cashew farming as profitable. Farming ventures interest $73.3 \%$ of the unemployed graduates while $66.7 \%$ would want to venture into cashew farming. 52.2\% of the job-seeking graduates had a favourable level of perception about cashew production. The perception of the job-seeking graduates is satisfactory as the favourability of their level of perception to cashew production is a little above average. Feasible loans or grants should be made available and easily accessible to job-seeking graduates to promote their involvement in cashew farming.

KEYWORDS: Cashew, Perception, Unemployed, Farming, Graduates, Production. 


\section{INTRODUCTION}

Cashew (Anacardium Occidentale L.), is a well-known species of the Anacardiaceae family (Subbarao et al., 2011). It originated from Brazil but the Portuguese explorers introduced it to Nigeria in the 15th and 16th centuries (Asogwa et. al., 2008) which was then used majorly for afforestation purposes and erosion control. The commercialization of cashew started in 1953 in Nigeria (Akinwale and Esan, 1989) and is now cultivated in about 20 states with Kogi, and Oyo state among the major cultivators. Cashew trees produce important edible nuts which are in major demand in the global market (Tola and Mazengia, 2019) with Nigeria known as one of its leading producers. The tree brings sustainable revenue to both farmers and local buyers (Elijah, 2015). It is an important dollar-earning crop (Anon, 2017). Cashew farming is mostly practiced for its wood, apple and majorly the nut (Adeigbe, et. al., 2015). Traits of importance in cashew are nut size, tree height, the colour of apple, disease resistance and nut yield (Aliyu et. al., 2008) with a mature tree producing a yield within the range of 7-11 kg per annum (Adejo et. al., 2011).

There is a feasible decrease in nut yield of cashew in growing parts of Nigeria such as Oyo state due to a decline in the population of cashew farmers (Hammed et. al., 2008) and an increase in senile or moribund cashew trees in the growing parts of the country. According to the Food and Agriculture Organization (FAO, 2020), cashew production in Nigeria dropped from 800,000 tonnes in 2009 to 100,000 tonnes in 2019 making Nigeria currently ranked as the 14th producer of cashew from 1st as of 2009. Globally, Nigeria supplies about 2.52 percent share of the total global export of cashew nut which is very low in contrast to the output of other cashew producing countries such as Ivory Coast $(20.01 \%)$, India (18.76\%), Vietnam (7.15\%), Tanzania (5,68\%) and Benin (5.16\%) (Food and Agriculture Organization Statistics $\{$ FAOSTAT, 2019$)$. Among Nigerian agricultural export commodities, cashew ranked $5^{\text {th }}$ with 61,867 tonnes of cashew nuts exported (FAO, 2018) with cocoa beans, sesame seeds, bran wheat and palm kernel taking the first to fourth positions respectively. These low values call for concern thereby creating a need to increase cashew production.

Despite the importance of cashew to economic growth and development, the hidden prospect of the crop in Nigeria is yet to be tapped into (Asiru et. al., 2005). Currently, cashew tree products are not being fully taken advantage of for income making. Investment return in cashew farming ranges between 30 to 40 percent in 3-5 years after cultivation (Ingredient Sourcing Solution \{ISS\}, 2015); this implies that cashew cultivation is a money-making business. Some of the challenges currently facing cashew production in Nigeria include moribund trees, farmers with small farm holdings and deforestation (Aliyu et. al., 2008). The value chain of cashew has not been effectively tapped, despite its money-making prospects. (Adesanya et. al., 2021).

Unemployment most especially among the graduate youth is a critical problem in Nigeria today which is one of the factors responsible for social vice activities such as armed robbery, internet fraud, kidnapping and banditry. According to the National Bureau of Statistics (NBS, 2020), the rate of unemployment in Nigeria increased from 23.4\% in 2019 to $27.1 \%$ in 2020 and the rate of unemployment among the youth increased from $29.7 \%$ in 2018 to $34.9 \%$ in 2020 . This implies that 21.7 million Nigerians are unemployed of which 7.6 million are youth within the ages of 15 to 34 years. In the absence of white-collar jobs for the graduate youths, agricultural ventures such as cashew production or engaging in one or more of its value chains can help reduce unemployment in the society creating good income for the youth and also contributing 
directly to an increase in the production of cashew and its products. Oyo state is a major cashew-producing state in Nigeria with an unemployment rate of $17.99 \%-19.64 \%$ (Statista, 2020) with a high rate of unemployment among its graduate youth.

Some of the opportunities involved in cashew production include cultivation for the apple, nuts, or both for local consumption or export, cashew seedling production, processing, marketing and export which can help address the problem of unemployment among Nigerian youth and thereby contributing to the increase in production of cashew. The various stages of the cashew value chain can be grouped into input supply, farm production, post-harvest handling e.g drying, marketing and transportation, processing, export and consumption. The identified stages of cashew production and processing serve as a source of revenue for farmers (Adeigbe, et. al., 2015). The investors in the cashew nut value chain are expected to provide job opportunities for the overcrowded Nigerian youths (Adesanya et. al., 2021) which indirectly contributes to the national revenue and gross domestic product of the country.

Therefore, the objective of this study is to:

1. Understand the perception of job-seeking graduates in Oyo state to cashew production.

2. Identify ways of increasing the production of cashew among job-seeking graduates in Oyo state.

\section{METHODOLOGY}

\section{Study Area}

The study was conducted in Oyo State with the coordinate $8.1574^{\circ} \mathrm{N}, 3.6147^{\circ} \mathrm{E}$ located in the South Western area of Nigeria. It is ranked $5^{\text {th }}$ as the most populated state in Nigeria. The ecological form of Oyo State is that of guinea savannah in the north and rain forest in the south.

\section{Sampling}

Purposive sampling was used in selecting areas considered which were Ibadan, Oyo and Ogbomoso. High population, high numbers of graduates and involvement in cashew production and its value chain were of paramount importance in the selection of the surveyed areas. Purposive sampling was also used in selecting 270 respondents, 90 each from the 3 areas as the respondents were either job-seeking graduate youths or unemployed but running a not too sustainable business before participating in the survey.

\section{Data Collection}

A physical approach was used at each of the selected areas as data were collected using questionnaires. The data collected were socio-demographic characteristics of the respondent (sex, age, marital status, area of residence, academic qualification, course of study and number of years after graduation), awareness on cashew tree and its importance, opinion of respondents to cashew farming, perception of respondents to money-making opportunities in cashew production and categorization of the respondents based on their level of perception. 


\section{Data Analysis}

Data obtained were analyzed using SPSS statistical package (version 22). Descriptive statistics such as frequency table, percentage were used and relationships were tested using chi-square.

\section{RESULT AND DISCUSSION}

Table 1 on socio-economic characteristics of the job-seeking youths showed that $61.1 \%$ are male while $38.9 \%$ are female. The majority (45.5\%) are within the age range of $30-34$ years while $35.6 \%$ are within the age range of $25-29$ years which indicate that a larger population of the job-seeking youths are still in their productive youthful period which gives them an edge for a favorable result if involved in cashew production. 55.6\% and 37.7\% had B.Sc. and postgraduate. qualifications respectively which show that they are well learned in their various professional fields. A very sizable amount of the youths studied Agricultural science-related courses $(37.8 \%)$ followed by Engineering related courses (15.6\%). 52.2\% had graduated 1-5 years, $40 \%$ had graduated between 6-10 years while 3.3\% had graduated over 10 years which indicates that graduate youths have not been getting white-collar jobs immediately after graduation.

Table 1: Socio-economic characteristics of the respondents

\begin{tabular}{lll}
\hline Socio-economic characteristics & Frequency & Percentage \\
\hline Gender & 165 & 61.1 \\
Male & 105 & 38.9 \\
Female & & \\
Age & 24 & 8.9 \\
$20-24$ & 96 & 35.6 \\
$25-29$ & 123 & 45.5 \\
$30-34$ & 27 & 10 \\
$35-39$ & & \\
Marital Status & 156 & 57.8 \\
Single & 114 & 42.2 \\
Married & & \\
Area of residence & 90 & 33.3 \\
Ibadan & 90 & 33.3 \\
Oyo & 90 & 33.3 \\
Ogbomoso & & \\
Level of education & 150 & 55.6 \\
Bachelor of Science (B.Sc.) & 102 & 37.7 \\
Post-Graduate & 18 & 6.7 \\
Others & & \\
Course of study & 102 & 37.8 \\
Agricultural science & 6 & 2.2 \\
Languages & 36 & 13.3 \\
Basic sciences & 30 & 11.1 \\
Medicine & 3 & 1.1 \\
Earth sciences & &
\end{tabular}




\begin{tabular}{lll} 
Engineering & 42 & 15.6 \\
Social science & 21 & 7.8 \\
Management sciences & 6 & 2.2 \\
Computer science & 9 & 3.3 \\
Pharmacy & 6 & 2.2 \\
Food science & 9 & 3.3 \\
Number of year(s) after graduation & & \\
0 & 12 & 4.4 \\
$1-5$ & 141 & 52.2 \\
$6-10$ & 108 & 40.0 \\
Above 10 & 9 & 3.3 \\
\hline
\end{tabular}

Source: Field survey: 2021

The table 2 on the distribution of respondents by their awareness on cashew tree and its importance showed that $96.3 \%$ knows what a cashew tree is which signifies that cashew tree is a popular tree. $99.6 \%$ of the respondents can identify cashew nut which showed that cashew nut is a well-known nut. $83.3 \%$ know what a cashew apple is while $16.7 \%$ have no idea. $90.7 \%$ knows the economic importance of cashew tree while $87.4 \%$ knows cashew nut as a major export commodity in Nigeria which shows that the economic importance of cashew as a major export crop is widely known. $89.3 \%$ know cashew farming to be profitable.

Table 2: Distribution of respondents by their awareness of Cashew tree and its importance

\begin{tabular}{|c|c|c|}
\hline Awareness of Cashew tree and its importance & Yes & No \\
\hline Do you know what a cashew tree looks like & $\overline{260(96.3)}$ & $\overline{10(3.7)}$ \\
\hline Can you identify cashew nuts? & $269(99.6)$ & $1(0.4)$ \\
\hline Can you identify cashew apples? & $225(83.3)$ & $45(16.7)$ \\
\hline Cashew trees are of economic importance. & $245(90.7)$ & $\overline{25(9.3)}$ \\
\hline Cashew nut is a major export commodity in & $236(87.4)$ & $34(12.6)$ \\
\hline \multicolumn{3}{|l|}{ Nigeria. } \\
\hline Cashew farming is profitable. & $241(89.3)$ & $29(10.7)$ \\
\hline $\begin{array}{l}\text { Nigeria is one of the leading producers of cashew } \\
\text { nuts. }\end{array}$ & $170(63.0)$ & $100(37.0)$ \\
\hline
\end{tabular}

Source: Field survey, 2021. Values in parentheses ( ) are percentages

Table 3 on the distribution of respondents according to their opinion on cashew farming showed that $73.3 \%$ had a positive opinion about their interest in farming ventures which implies the majority are interested in farming. It is easier to get land on lease for farming than from family/friends and owning one as respondents had a positive opinion of $54.4 \%, 46.6 \%$ and $40 \%$ respectively. $95.5 \%$ had a positive opinion on farming being profitable. The majority of the respondent had a positive opinion on the commercialization of cashew as well known (78.9\%), a money-making venture $(91.1 \%)$, willingness to venture into cashew farming $(66.7 \%)$, cashew farming as prestigious (74.4\%), awareness on available training (46.6\%) and their availability for any cashew farming training $(81.1 \%)$. 
Table 4 shows the perception of respondents to money-making opportunities in cashew production. $58.9 \%$ prefer cultivation for the nuts, $15.6 \%$ prefer cultivation for the apple which has the lowest response of all the money-making opportunities. This indicates that the economic importance of the cashew apple is not well-known and established among the youths. Export had the highest response of $68.9 \%$ which shows that the majority prefers exportation among the money-making opportunities considered while processing and cashew seedling production had $44.4 \%$ and $35.6 \%$ respectively.

Table 3: Distribution of the respondents according to their opinion on cashew farming

\begin{tabular}{|c|c|c|c|c|c|c|c|}
\hline $\begin{array}{l}\text { Opinion of the respondent } \\
\text { to cashew farming }\end{array}$ & $\underline{\mathbf{S A}}$ & $\underline{\mathbf{A}}$ & $\underline{\mathbf{U}}$ & $\underline{\mathbf{D}}$ & $\underline{\text { SD }}$ & $\underline{\text { Mean }}$ & $\frac{\text { Standard }}{\text { Deviation }}$ \\
\hline Farming venture interests me & $\frac{111}{(41.1)}$ & $\frac{114}{(32.2)}$ & $\frac{33}{(12.2)}$ & $\underline{6} \underline{(2.2)}$ & $\underline{6}(2.2)$ & $\underline{4.18}$ & $\underline{0.89}$ \\
\hline $\begin{array}{l}\text { I can easily get land of my } \\
\text { own for farming }\end{array}$ & $\frac{48}{(17.8)}$ & $\underline{\frac{30}{(22.2)}}$ & $\frac{66}{(24.4)}$ & $\frac{66}{(24.4)}$ & $\underline{30}$ & $\underline{3.11}$ & $\underline{1.28}$ \\
\hline $\begin{array}{l}\text { I can easily get land from } \\
\text { family and friends for } \\
\text { farming }\end{array}$ & $\frac{60}{(22.2)}$ & $\frac{66}{(24.4)}$ & $\frac{69}{(25.6)}$ & $\frac{48}{(17.8)}$ & $\begin{array}{l}\frac{27}{(10.0)} \\
(10)\end{array}$ & $\underline{3.31}$ & $\underline{1.28}$ \\
\hline $\begin{array}{l}\text { I can easily get land on lease } \\
\text { for farming }\end{array}$ & $\frac{33}{(12.2)}$ & $\frac{114}{(42.2)}$ & $\frac{63}{(23.3)}$ & $\frac{42}{(15.6)}$ & $\frac{18}{(6.7)}$ & $\underline{3.38}$ & $\underline{1.10}$ \\
\hline $\begin{array}{l}\text { Farming is a profitable } \\
\text { venture }\end{array}$ & $\frac{174}{(64.4)}$ & $\underline{84}$ & $\underline{6}(2.2)$ & $\underline{6}(2.2)$ & $\begin{array}{l}\underline{0} \\
(0.0)\end{array}$ & $\underline{4.58}$ & $\underline{0.65}$ \\
\hline $\begin{array}{l}\text { Commercial cultivation of } \\
\text { cashew is well known }\end{array}$ & $\frac{87}{(32.2)}$ & $\frac{126}{(46.7)}$ & $\frac{27}{(10.0)}$ & $\frac{24}{(8.9)}$ & $\underline{6}(2.2)$ & $\underline{3.98}$ & $\underline{0.99}$ \\
\hline $\begin{array}{l}\text { Cashew farming is a money- } \\
\text { making venture }\end{array}$ & $\frac{126}{(46.7)}$ & $\frac{120}{(44.4)}$ & $\frac{24}{(8.9)}$ & $\begin{array}{l}\underline{0} \\
\underline{(0.0)}\end{array}$ & $\begin{array}{l}\underline{0} \\
\underline{(0.0)}\end{array}$ & $\underline{4.38}$ & $\underline{0.65}$ \\
\hline $\begin{array}{l}\text { I will love to venture into } \\
\text { cashew farming }\end{array}$ & $\frac{105}{(38.9)}$ & $\frac{75}{(27.8)}$ & $\frac{81}{(30.0)}$ & $\underline{3}$ & $\underline{6}(2.2)$ & $\underline{4.00}$ & $\underline{0.97}$ \\
\hline $\begin{array}{l}\text { Cashew farming is } \\
\text { prestigious }\end{array}$ & $\frac{90}{(33.3)}$ & $\frac{111}{(41.1)}$ & $\frac{60}{(22.2)}$ & $\underline{3}$ & $\frac{6}{(2.2)}$ & $\underline{4.02}$ & $\underline{0.90}$ \\
\hline $\begin{array}{l}\text { There are available trainings } \\
\text { on cashew farming }\end{array}$ & $\frac{33}{(12,2)}$ & $\frac{93}{(34.4)}$ & $\frac{81}{(30.0)}$ & $\frac{45}{(16.7)}$ & $\frac{18}{(6.7)}$ & $\underline{3.29}$ & $\underline{1.09}$ \\
\hline $\begin{array}{l}\text { I will be available for any } \\
\text { cashew training }\end{array}$ & $\frac{114}{(42.2)}$ & $\frac{105}{(38.9)}$ & $\frac{26}{(13.3)}$ & $\frac{12}{(4.4)}$ & $\underline{3}$ & $\underline{4.17}$ & $\underline{0.90}$ \\
\hline
\end{tabular}

Source: Field survey, 2021. Strongly Agree (SA), Agree (A), Undecided (U), Disagree (D), Strongly Disagree (SD). Values in parentheses ( ) are percentages. 
Table 4: Perception of respondents to money-making opportunities in cashew production

\begin{tabular}{|c|c|c|}
\hline Money making opportunities in cashew production & Frequency & Percentage \\
\hline Cultivation for the nuts & 159 & 58.9 \\
\hline Cultivation for the apple & 42 & 15.6 \\
\hline Marketing & $\overline{93}$ & $\overline{34.4}$ \\
\hline Export & 186 & 68.9 \\
\hline Cashew seedling production & $\overline{96}$ & $\overline{35.6}$ \\
\hline Processing & $\overline{120}$ & $\overline{44.4}$ \\
\hline Storage and warehousing & $\overline{87}$ & $\overline{32.2}$ \\
\hline Consultancy and management services & $\underline{96}$ & 35.6 \\
\hline
\end{tabular}

Source: Field survey, 2021

Table 5 shows that $52.2 \%$ of the respondents had a favorable perception of cashew production while 47.8 had an unfavourable perception of cashew production which indicates that more than half of the job-seeking graduates favours cashew production.

Table 5: Categorization of the respondents based on their level of perception

\begin{tabular}{llll}
\hline Level of Perception & Categorization & Frequency & Percentage \\
\hline Favourable & $\underline{\geq 3.85}$ & $\underline{141}$ & $\underline{52.2}$ \\
\hline$\underline{\text { Unfavourable }}$ & $\underline{\mathbf{1 2 9}}$ & $\underline{47.8}$ & $\underline{3.85}$ \\
\hline
\end{tabular}

Source: Field survey, 2021 Overall mean $=3.85$

Table 6 shows that gender and area of residence had a significant relationship with the level of perception of the respondent to cashew farming which indicates that gender and area of residence influenced the perception of respondents to cashew production.

Table 6: Relationship between selected socio-economic characteristics of the respondents and the level of perception of the respondent to cashew farming in the study area.

\begin{tabular}{lll}
\hline Socio-economic characteristics & Chi-square & p-value \\
\hline Gender & $\underline{6.242}$ & $\underline{0.012^{*}}$ \\
\hline Marital status & $\underline{0.621}$ & $\underline{0.431}$ \\
Area of residence & $\underline{7.036}$ & $\underline{0.030^{*}}$ \\
$\underline{\text { Academic qualification }}$ & $\underline{5.801}$ & $\underline{0.122}$ \\
\hline Course of study & $\underline{6,664}$ & $\underline{0.757}$ \\
\hline
\end{tabular}

* Represents significant differences. 
Table 7 shows that availability of land to farm, little or no knowledge in cashew farming and little or no understanding of the value of crop had a significant relationship with the level of perception of the respondent to cashew farming. This indicates that availability of land to farm, little or no knowledge in cashew farming and little or no understanding of the value of crop influenced youth's perception in engaging in cashew farming.

Table 7: Relationship between the level of perception of the respondent to cashew farming and constraints militating against cashew farming in the study area

\begin{tabular}{lll}
\hline Constraints to youth participation in cashew production & $\underline{\text { Chi-square }}$ & p-value \\
\hline Lack of fund & $\underline{0.260}$ & $\underline{0.610}$ \\
\hline Availability of land to farm & $\underline{4.613}$ & $\underline{0.032^{*}}$ \\
\hline Little to no knowledge in cashew farming & $\underline{4.609}$ & $\underline{-0.031^{*}}$ \\
\hline Little to no understanding of the value of crop & $\underline{0.022}$ & $\underline{\underline{0.035^{*}}}$ \\
\hline The 3 to 4 years wait before fruiting & $\underline{0.881}$ \\
Poor knowledge of its value chain & $\underline{1.309}$ & $\underline{0.253}$ \\
Little or no knowledge about the marketing of cashew products & $\underline{0.027}$ & $\underline{0.869}$ \\
$\underline{\text { Little or no knowledge about processing, processing machines or }}$ & $\underline{0.618}$ & $\underline{0.106}$ \\
$\underline{\text { equipment }}$ & $\underline{0.074}$ & $\underline{0.786}$ \\
$\underline{\text { Ansecurity }}$ & $\underline{0.239}$ & $\underline{0.625}$ \\
$\underline{\text { Pilfering (theft) }}$ & $\underline{1.263}$ & $\underline{0.261}$ \\
\hline
\end{tabular}

* Represents significant differences.

\section{CONCLUSION}

A larger population of job-seeking graduates are still in their prolific youthful age, welleducated and unemployed for about an average of 4.98 years. Creating job opportunities for this population by engaging them in cashew farming or any of its value chains will help increase the decline experienced in cashew production and output thereby serving as a job opportunity and a major source of sustainable income for the job-seeking youths.

The overall perception of the job-seeking graduates is satisfactory as the favourability of their level of perception to cashew production is a little above average. Therefore to increase this, more effort must be put into awareness, training, funding and empowerment programs targeted at youths to improve the perception of youths generally to cashew production which will in the long run increase production.

Cashew tree, its fruit are well known as a profitable economic and export crop in Nigeria, however necessary training and empowerment must be adopted to help monetize this knowledge thereby increasing cashew production.

The economic importance of cashew apples is not well known therefore more awareness and training on the importance of cashew apples must be encouraged and promoted.

Farmlands should be made available via the government farm settlement system to interested cashew farmers on long term lease and training on the value of cashew, cashew production, its agronomy, value chain, security and guarding should be regularly conducted by the 
government in collaboration with Cocoa Research Institute of Nigeria and other Institutes or organizations whose one of their mandate crops is cashew via mass media, social media platforms, lectures and seminars.

\section{RECOMMENDATION}

Research should be conducted in other cashew growing areas in Nigeria such as Kogi, Osun and Kwara state in order to understand the perception of job-seeking graduates to cashew production from which a national recommendation can be made to increase cashew production in Nigeria.

Acknowledgement: I want to appreciate Dr. SamGoforth Ajani for his contribution towards the project topic and his effort towards the administration of the questionnaire of this project. I also want to appreciate the contacted brethren of TARM Ibadan and Ogbomoso centre for their participation in administering the questionnaire.

\section{REFERENCES}

Adeigbe, O. O., Olasupo, F. O., Adewale, B. D. and Muyiwa, A. A. (2015). A review on cashew research and production in Nigeria in the last four decades. Academic Journal. 2015; Vol. 10(5), pp. 196-209.

Adejo, P. E., Otitolaye, J. O.and Onuche, U. (2011). Analysis of marketing channel and pricing system of cashew nuts in North Central Nigeria, Journal of Agricultural Science. 3(3): 246-248.

Adesanya, K. A., Agboola-Adedoja, M. O., Adelusi, A. A., Ogunwolu, Q. A., Ugwu, C. A., Alli, M. A. and Akinpelu, A. O. (2021). Opportunities in Nigerian cashew nut value chain. World Journal of Advanced Research and Reviews, 09(01), 168-174

Akinwale, S. A. and Esan, E. B. (1989). Advances in Cashew Breeding in Nigeria in Progress in Tree Crop Research. 2nd Edn. Cocoa Research Institute of Nigeria, Ibadan. Pp.166174

Aliyu, O. M. and Hammed, L. A. (2008). Nigerian cashew economy: A review of nut production sector. Paper presented at the International Academy of African Business and Development (IAABD) Conference. University of Florida, Gainesville, USA. 2024 May 2008.

Anonymous. (2017). Horticultural Statistics at a Glance 2017 - National Horticulture Board.

Asiru, W. B., Komolafe, A. O., Akinose, R. (2005): Processing of cashew nut in: Raw update cocoa Rebirth of major Economic cash crop. Raw materials update. (Eds): Abdullahi,

A. K, Thompson K, Omotoso O, Asanga E, Obasi S.C. Publication of the Raw Materials Research and Development Council, Abuja. 6 (1): 32.

Asogwa, E. U., Hammed, L. A. and Ndubuaku, T. C. N. (2008). Integrated production and protection practices of cashew (Anacardium occidentale) in Nigeria. African Journal of Biotechnology. 7(25):4868-4873.

Elijah, A. T. (2015). Cashew Nut Shell Oil-A Renewable and Reliable Petrochemical Feedstock Nigeria. Published by Intech open science/open mind World's largest Science, Technology \& Medicine. Open Access book publisher etaiwo@oauife.edu.ng,eataiwo@yahoo.com 
Food and Agriculture Organization (FAO) (2019). FAOSTAT Statistical Database, Statistical Division. Rome.

Food and Agriculture Organization (FAO). (2018). Cashew industry and production.

Food and Agriculture Organization (FAO). (2020). Cashew industry and production:

Hammed, L. A., Anikwe, J. C. and Adedeji, A. R. (2008) Cashew nuts and production development in Nigeria. American-Eurasian Journal of Scientific Research. 3(1):54-61.

Ingredient Sourcing Solution (2015). The World Cashew Market and the Opportunity in Processing, presented at SIETTA 2016.

National Bureau of Statistics (NBS, 2020). Statistical News. Retrieved from www.nbs.org.ng/unemployment-in- Nigeria. Last accessed on 21/06/2021.

Statista. (2020) https://www.statista.com/statistics/1119533/unemployment-rate-in-nigeriaby-state/. Accessed 06/07/2021.

Subbarao, C.N.V., Krishna, P.K.M.M. and Prasad V.S.R.K. (2011). Nut Shell Oil -A Renewable and Reliable Petrochemical Feedstock Cashew. Parma. Res. Journal. 6(1): 21- 41.

Tola, J., \& Mazengia, Y. (2019). Cashew production benefits and opportunities in Ethiopia: A Review. Journal of Agricultural and Crop Research, 7(2), 18-25. https://doi.org/10.33495/jacr_v7i2.19.105 